\title{
Intraocular Pressure
}

National Cancer Institute

\section{Source}

National Cancer Institute. Intraocular Pressure. NCI Thesaurus. Code C87143.

The fluid pressure within the eye. 